Raf. J. Sci.,Vol.28, No.2 Special Issue for the Third Scientific Conference of Chemistry, pp.120-126, 2019

\title{
Electrochemical Study of Theophylline - Urea Interaction Using Square Wave Voltammetry
}

\author{
Asmaa M. Al-Hasany* \\ Department of Mining Engineering/ College of Petroleum and Mining Engineering/ \\ University of Mosul \\ Haitham A. Al-Wahb Amer Th. Al-Taee \\ Department of Chemistry/ College of Science/ University of Mosul \\ E-mail: rosefirst78@yahoo.com*
}

(Received 18/9/2018 ; Accepted 25/10/2018)

\begin{abstract}
In this work, the interaction between theophylline (TP) which gives a stable well-defined reduction peak at (1.07) V versus $\mathrm{Ag} / \mathrm{AgCl}$. Sat. $\mathrm{KCl} /$ in phosphate buffer solution $(\mathrm{pH}=7)$ and urea was studied using square wave voltammetry (SWV) technique. Also, the binding constant and the thermodynamics parameters have been calculated. Different temperatures $(288,293,298,298,303$, 308 and 310$)^{\circ} \mathrm{K}$ were used to study the effect of temperature on binding constant $(\mathrm{K})$. The results showed that the binding constant $(\mathrm{K})$ decreased with increasing temperature. This is as a result of the negative value of enthalpy $(-31.07) \mathrm{KJ} \cdot \mathrm{mol}^{-1}$. The negative value of Gibbs energy $(-13.632 \mathrm{x}$ $\left.10^{2}-12.296 \times 10^{2}\right) \mathrm{KJ}^{2} \mathrm{~mol}^{-1}$ indicates that the interaction is spontaneous and could be due to van der Waals forces or hydrogen bonds effect (weak interaction).
\end{abstract}

Keywords: Theophylline, Urea, Interaction, Modified electrode.

\section{درلسة السلوك الكهوكيميائي الدلل الثيوفلن - يوربا بلستخدلمفولتامتري الموجة المربمة}

\section{الملغص}

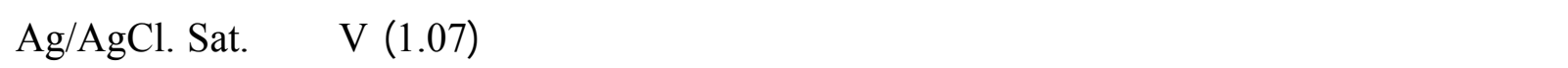

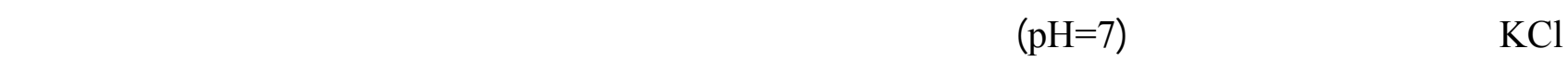
والعولمل الثيرمودلينميكية. ولستخدت الدرجلت الحرارية المختلفة (288، 293، 298، 303، 308 و 310) مكلفن في درلسة

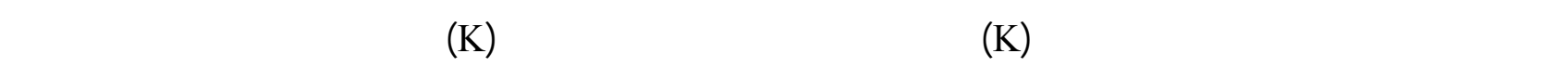

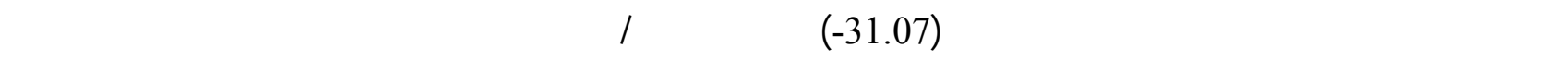

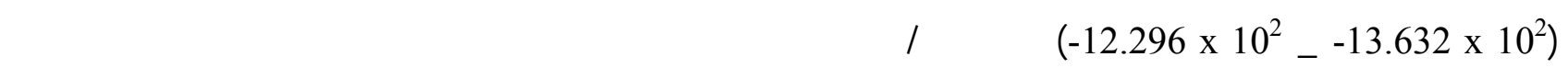
التأصر الهيدروجيني (تدلخل ضعيف). الهاملت الدالة: ثيوفلين، يوريا، تدلخل، قطب مطور. INTRODUCTION

Theophylline (1,3-dimethylxanthine) as a xanthine derivative has been commonly used as an additional treatment drug in the asthmatic acute phase in children and asthma and bronchospasm in adults (Fuyong Jiao et al., 2018; Igarashi and Iwakawa, 2009; Kanehara et al., 2008; Kawai and Kato, 2000). It is also used clinically as diuretic, cardiac stimulant and smooth muscle relaxant 
(Blake and Kamada, 1996; Weinberger and Hendeles,1996; Minton and Henry, 1996). Thus, more and more scientists have paid increasing attention to the techniques for the quantitative determination of theophylline. The chemical structure of theophylline is shown in Fig. (1).

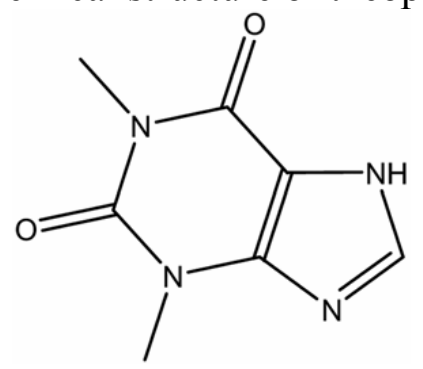

Fig. 1: The chemical structure of theophylline

At present, many methods have been employed for measuring theophylline quantitatively, such as liquid chromatography (Kalyani et al., 2017; Srdjenovic et al., 2008), UV spectrometry (Sujana et al., 2016; Culzoni et al., 2005), chemiluminescent immunoassay (Zhou et al., 2005), gas chromatographymass spectrometry (GC-MS)and gas chromatography-isotope dilution mass spectrometry (GC-IDMS) ( Arinobu et al., 2009; Kress et al., 2002). Nevertheless, some of these methods, such as chromatography and mass spectrometry, are time-consuming, expensive and need complicated preconcentration or multisolvent extraction as well as trained technicians. Instead, electrochemical methods are characterized by simplicity, high sensitivity, good stability, low-cost instrumentation on-site monitoring (Sadik et al., 2003). Thus, they are exploited for the determination of theophylline.

Urea $[(\mathrm{NH} 2) 2 \mathrm{CO}]$ is one of the chief human nitrogen-based metabolic wastes. The urea concentration in serum or urine indicates kidney diseases and diabetes, and its analysis in clinical laboratories is very frequent (Branzoi et al., 2011; Singh et al., 2008). However, the urea quantification uses conventional methods, such as spectrophotometric, potentiometry, and piezoelectricity (Singh et al., 2008), which are expensive and time consuming. Therefore, it is very important to develop simple, sensitive, and accurate methods for urea detecting. A variety of analytical methods have been developed and used to analyze urea in aqueous samples. As a result, voltammetric sensors have become an excellent alternative for detecting various analyses, including urea. Since urea is electroactive and most of the electroanalytical techniques are selective, highly sensitive, time-saving, inexpensive, have a wide dynamic range, and a quick response, electrochemical techniques have been used to determine urea as a strong alternative to the other methods. Various forms of modified electrodes have been used for electrochemical studies of urea because of their unusual characteristics (Harish et al., 2018; Branzoi et al., 2011; Singh et al., 2008; Hamilton, 2012 ; Yang et al., 2004).

\section{Apparatus}

\section{EXPERIMENT}

All the electrochemical experiments were performed using a797VA Computrace instrument (Metrohm, Switzerland). The reference electrode was an $\mathrm{Ag} / \mathrm{AgCl}$ with saturated $\mathrm{KCl}$ and a platinum wire was used as the auxiliary electrode and a glassy carbon electrode GC used as the working electrode.

pH measurements were performed by using a digital $\mathrm{pH}$ meter (HANNA(, Italy, calibrated with standard buffers. The Haake Heated Water Bath Circulator is Model G, USA. 


\section{Chemicals and Reagents}

All chemicals used in this work (urea, theophylline, dipotassium hydrogen phosphate $\mathrm{K}_{2} \mathrm{HPO}_{4}$, and potassumdihydrogen phosphate $\mathrm{KH}_{2} \mathrm{PO}_{4}$ ) were of analytical grade and used without further purification, and were purchased from Fluka, and BDH.

\section{Electrochemical Behaviour of Theophylline}

\section{RESULTS AND DISCUSSION}

The square wave voltammogram was recorded using $\left(9.090 \times 10^{-5}\right) \mathrm{M}$ theophylline (TP) in phosphate buffer solution under the default instrument. After that the optimum conditions of TP has been studied, and the voltammograms of $\left(9.090 \times 10^{-5}\right) \mathrm{M}$ of TP Fig. (2) were recorded under each effective parameter and the results obtained are summarized in (Table 1).

\section{Table 1: Default and the optimum conditions of TP}

\begin{tabular}{|c|c|c|}
\hline Condition & Defaultconditions & Optimum conditions of TP \\
\hline Start Potential (V) & 0.4 & 0.4 \\
\hline End Potential (V) & 1.4 & 1.4 \\
\hline Deposition potential (V) & -0.9 & -1.5 \\
\hline Deposition time (s) & 60 & 50 \\
\hline Equilibration time (s) & 5 & 5 \\
\hline Voltage step (V) & 0.006 & 0.002 \\
\hline Amplitude (V) & 0.02 & 0.03 \\
\hline Frequency (Hz) & 50 & 100 \\
\hline Sweep rate & 0.3 & 0.1984 \\
\hline
\end{tabular}
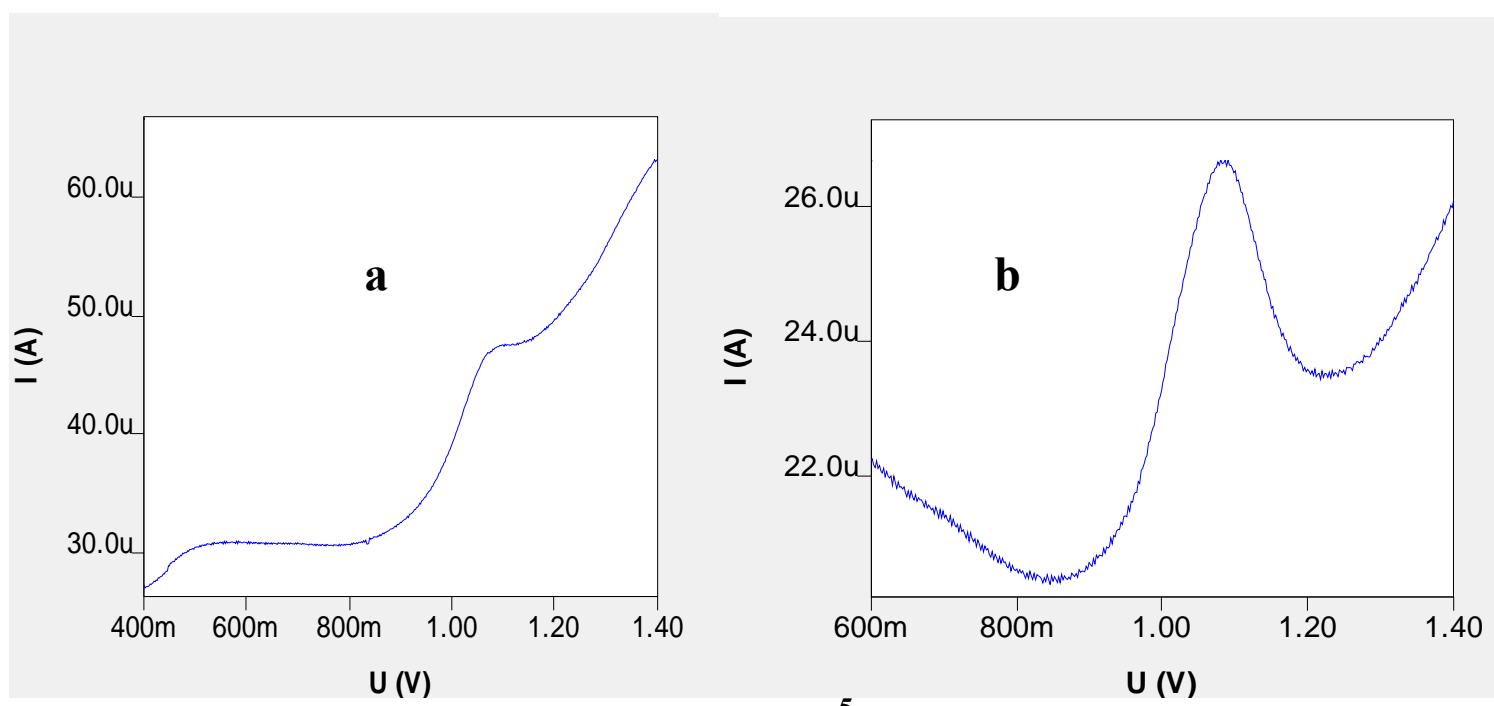

Fig. 2: The voltammogram of TP $\left(9.090 \times 10^{-5}\right) \mathrm{M}$ (a)under the default conditions, (b) under the studied optimum conditions

\section{Effect of Urea on Theophylline Reduction Peak}

The effect of urea on TP peak was studied by adding sequence additions of urea $\left(72.595 \times 10^{-3}-79.915 \times 10^{-3}\right) \mathrm{M}$ on $(0.0002) \mathrm{M}$ of TP; adecrease in the TP current peek was observed with the sequence additions of urea Fig. (3). 


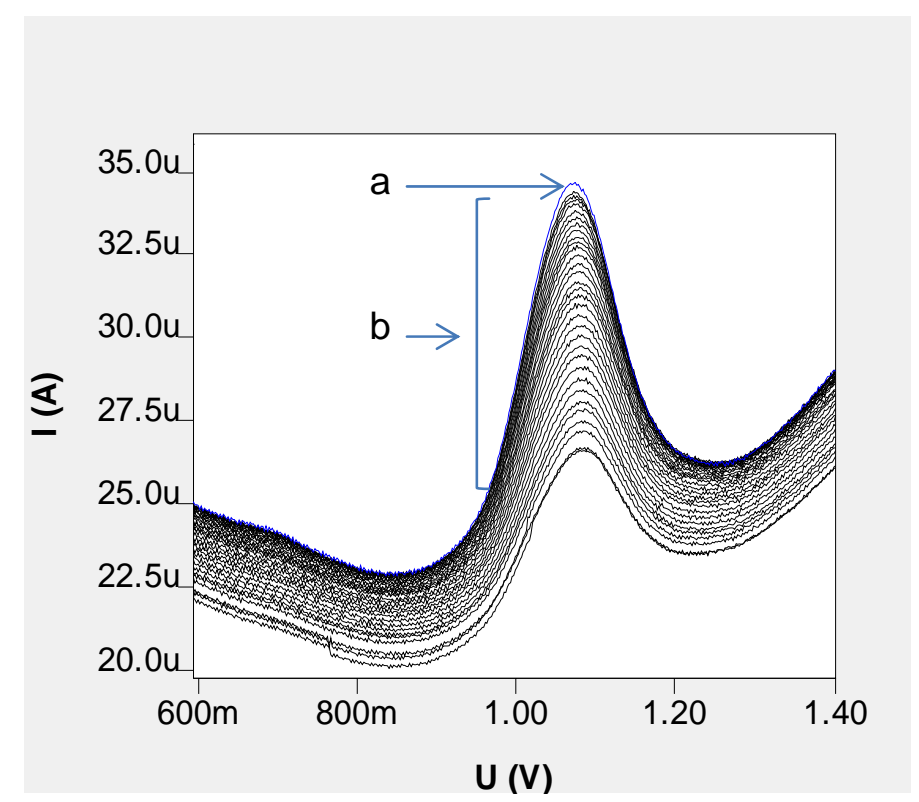

Fig. 3: The voltammograms of TP (0.0002) $M($ a) in the absence of urea

(b) in the presence of urea $(72.595 \times 10-3-79.915 \times 10-3) \mathrm{M}$

\section{Stability of Theophylline Reduction Peak in the Presence of Urea}

The stability of TP voltammogram $\left(8.84956 \times 10^{-5}\right) \mathrm{M}$ in the presence of urea $\left(2.654 \times 10^{-3}\right) \mathrm{M}$ was measuredat different times, using phosphate buffer solution $(\mathrm{pH}=7)$ under the previous optimum conditions of TP and the results are shown in (Table 2). The results indicate that the interaction peak was stable within the studied time (120) $\mathrm{min}$.

Table 2: Stability of theophylline reduction peak in the presence of urea

\begin{tabular}{|c|c|c|}
\hline Time (min) & Ep.(V) & Ip. $(\boldsymbol{\mu A})$ \\
\hline 0 & 1.05 & 7.020 \\
\hline 10 & 1.05 & 7.260 \\
\hline 20 & 1.05 & 6.810 \\
\hline 50 & 1.05 & $7 . .070$ \\
\hline 60 & 1.05 & 7000 \\
\hline 70 & 1.05 & 6.970 \\
\hline 80 & 1.05 & 7.140 \\
\hline 90 & 1.05 & 7.170 \\
\hline 100 & 1.05 & 7.091 \\
\hline 110 & 1.05 & 7.150 \\
\hline 120 & 1.05 & 7.030 \\
\hline
\end{tabular}

\section{Thermodynamic Calculations}

The binding constant of theophylline-urea was calculated according to the equation (1).

$$
\ln \left(\mathrm{Ip} /\left(\mathrm{Ip}^{\mathrm{o}}-\mathrm{Ip}\right)\right)=\ln (1 /[\mathrm{Conc} .(\mathrm{M})])-\ln (\mathrm{K})
$$

Where $\mathrm{Ip}^{\mathrm{o}}$ is the reduction current of TP alone, Ip is the reduction current of TP-urea complex, Conc. is the molar concentration of $\mathrm{TP}$, and $(\mathrm{K})$ is the binding constant of TP-urea complex.

The binding constant was calculated at different temperatures $(288,293,298,303,308,310)$ $\mathrm{K}^{\mathrm{o}}$, and the results are shown in Fig. (4). 

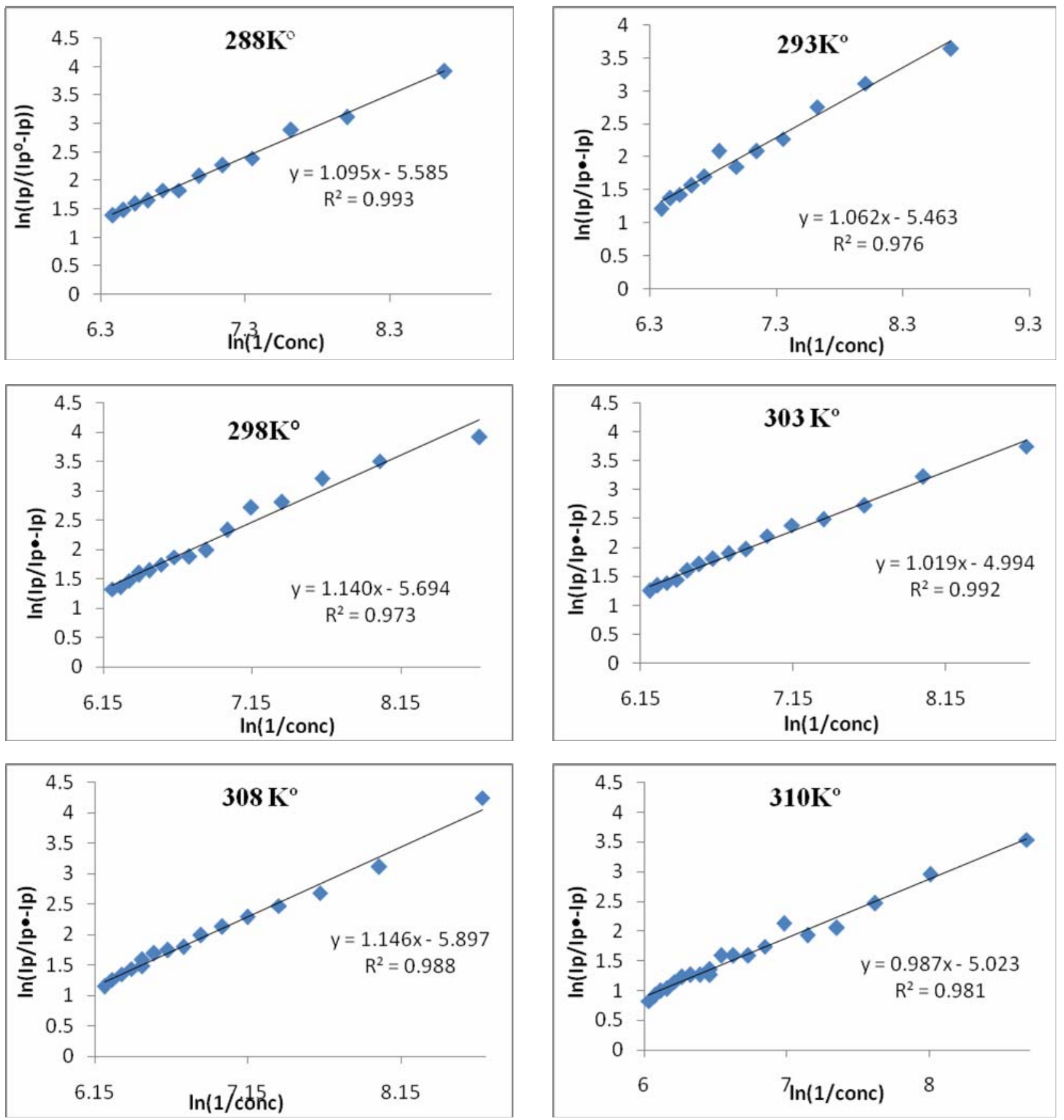

Fig. 4: Plot of $\ln \left(\mathrm{Ip} /\left(\mathrm{Ip}^{\mathrm{o}}-\mathrm{Ip}\right)\right)$ vsln $(1 /[\mathrm{Conc} .(\mathrm{M})])$ at $(288,293,298,298,303,308,310)^{\circ} \mathrm{K}$

Thermodynamic parameters were calculated Fig. (5) according to the equations (2) for Van't Hoff eq. and (3), the binding constant at different temperatures are shown in (Table 3).

$\ln \mathrm{K}=\frac{\Delta \mathrm{H}}{\mathrm{RT}}+\frac{\Delta \mathrm{S}}{\mathrm{R}}$

$\Delta \mathrm{G}=-\mathrm{R} \mathrm{T} \ln \mathrm{K}$ 


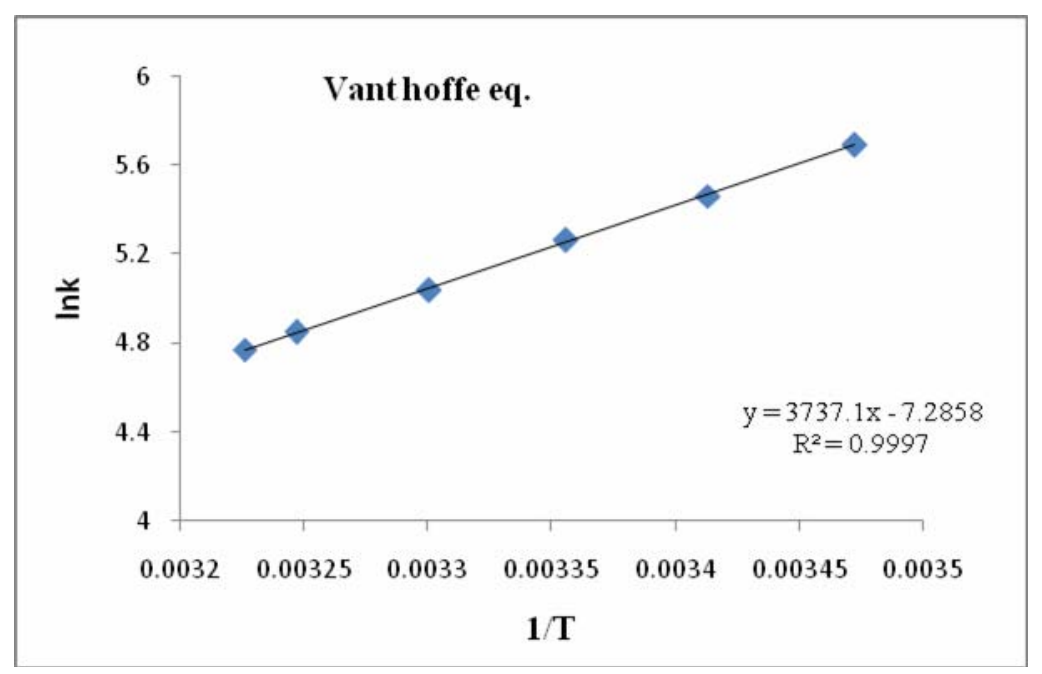

Fig. 5: Plot of In K vs 1/T

Table 3: The relation between binding constant and temperature

\begin{tabular}{|c|c|c|c|c|c|}
\hline $\mathbf{T}\left(\mathbf{K}^{\mathbf{0}}\right)$ & $\operatorname{Ln} \mathbf{K}_{\mathbf{b}}$ & $\begin{array}{l}\text { The binding constant } \\
\qquad K_{b}\left(10^{2}\right) M\end{array}$ & $\begin{array}{c}\Delta \mathbf{H} \\
\left({\left.\mathrm{KJ} . \mathrm{mol}^{-1}\right)}^{-1}\right.\end{array}$ & $\begin{array}{c}\Delta \mathbf{G} \\
\left(\mathrm{KJJmol}^{-1}\right)\end{array}$ & $\begin{array}{c}\Delta S \\
\left(J^{-m o l^{-1}} \cdot \mathbf{K}^{-1}\right)\end{array}$ \\
\hline 288 & 5.693 & 2.968 & \multirow{6}{*}{-31.070} & -13.632 & \multirow{6}{*}{-60.6} \\
\hline 293 & 5.463 & 2.358 & & -13.308 & \\
\hline 298 & 5.263 & 1.930 & & -13.039 & \\
\hline 303 & 5.038 & 1.541 & & -12.691 & \\
\hline 308 & 4.851 & 1.278 & & -12.422 & \\
\hline 310 & 4.771 & 1.180 & & -12.296 & \\
\hline
\end{tabular}

The negative value of $\Delta$ Sindicates that the interaction is ordered. The negative value of $\Delta$ Hmeans that the interaction is exothermic. From the values of $\Delta \mathrm{G}$, the spontaneity of interaction is decreased with increasing temperature. This agrees with negative value of $\Delta H$ showing that the type of interaction is hydrogen bonding or vander Waals forces. From the binding constant and thermodynamic results, we find that the interaction between TP and urea is week, exothermic, spontaneous and stable (Ross and Subramanian, 1981).

\section{CONCLUSION}

Square wave voltammetry technique is a good technique to study the interaction between TP and urea. Thermodynamics parameters give an idea about interaction type, negative value of enthalpy changemeans that the interaction was exothermic, negative value of entropy change indicates that the interaction became more ordered and the shifting of Gibss free energy value to more positive caused the spontaneousdecrease. From the thermodynamics parameters we can conclude that the interaction between TP and urea is due to either hydrogen bonding or vander Waals forces.

\section{REFERENCES}

Arinobu, T.; Hattori, H.; Kumazawa, T.; Lee, X.P.; Mizutani, Y.; Katase, T.; Kojima, S.; Omori, T.; Kaneko, R.; Ishii, A.; Seno, H. (2009). High-throughput determination of theophylline and caffeine in human serum by conventional liquid chromatography-mass spectrometry. Forensic. Toxicol., 27(1), 1-6.

Blake, K.; Kamada, A.K. (1996). "Textbook of Therapeutics: Drug and Disease Management". Williams and Wilkins: Baltimore, 6, 651 p.

Branzoi, V.; Musina, A.; Branzoi, F. (2011). Amperometric urea biosensor based platinum electrode modified with a composite film. Rev. Roum. Chim., 56(9), 883. 
Culzoni, M.J.; De Zan, M.A.; Robles, J.C.; Mantovani, V.E.; Goicoechea, H.C. (2005). Chemometries-assisted uv-spectroscopic strategies for the determination of theophylline insyrups. J. Pharmaceut. Biomed., 39(5),1068-1074.

Fuyong, J.; Nan, G.; Sheng, Z.; Yuhua, Y. (2018). A Clinical Analysis and Study of 110 Pediatric Cases with Aminophylline Poisoning. Pharmacol. and Clin. Research, 5, 2473-5574.

Hamilton, A. (2012). The Formation and Characterization of a Polypyrrole Based Sensor for the Detection of Urea. National University of Ireland, Maynooth, PhD Thesis.

Harish, M.; Parteek, P.; Sweta, R.; Beena, K.; Zaidi, M.G.H. (2018). "Electrochemical oxidationreduction and determination of urea at enzyme free PPY-GO electrode". Carbon Letters, 26, 88-94.

Igarashi, T.; Iwakawa, S. (2009). Effect of gender on theophylline clearance in japanese pediatric patients. Biol. Pharm. Bull., 32(2), 304-307.

Kanehara, M.; Yokoyama, A.; Tomoda, Y.; Shiota, N.; Iwamoto, H.; Ishikawa, N.; Taooka, Y.; Haruta, Y.; Hattori, N.; Kohno, N. (2008). Anti-inflammatory effects and clinical efficacy of theophylline and tulobuterol in mild-to-moderate chronic obstructive pulmonary disease Pulm. Pharmacol. Ther.,21, 874.

Kawai, M.; Kato, M. (2000). Theophylline for the treatment of bronchial asthma: present status Find. Exp. Clin. Pharmacol., 22(5), 309-320.

Kalyani, L.; Chava, V.; Rao, N. (2017). Development and validation of stability-indicating RPHPLC method for the simultaneous analysis of Salbutamol, Theophylline and Ambroxol. Saudi J. Med. and Pharm. Sci., 2413-4929.

Kress, M.; Meissner, D.; Kaiser, P.; Hanke, R.; Wood, W.G. (2002). Determination of theophylline by HPLC and GC-IDMS, the effect of chemically similar xanthine derivatives on the specificity of the method and the possibility of paracetamol as interfering substance. Clin. Lab., 48(9-10), 541-551.

Minton, N.A.; Henry, J.A. (1996). Acute and chronic human toxicity of theophylline. Human Exp. Toxicol., 15(6), 471-481.

Ross, D.P.; Subramanian, S. (1981). Thermodynamics of protein association reactions: forces contributing to stability. Biochemistry, 20, 3096-3102.

Sadik, O. A.; Land, W. H.; Wang, J. (2003). Targeting chemical and biological warfare agents at the molecular level. Electroanalysis., 15(14),1149-1159.

Sujana, K.; Venu, S.; Sravani, K.; Iswarya, P. (2016). simultaneous estimation of salbutamol and theophylline in bulk drugs and marketed formulation using simultaneous equation method. International J. Pharm. Tech. Research CODEN (USA), 9, 274-282.

Singh, M.; Verma, N.; Garg, A. K.; Redhu, N. (2008). Urea biosensors. Sensors and Actuators B: Chemical. Sensors and Actuators B., 134, 345.

Srdjenovic, B.; Djordjevic-Milic, V.; Grujic, N.; Injac, R.; Lepojevic, C. (2008). Simultaneous HPLC determination of caffeine, theophylline in food, drinks, and herbal products. $J$. Chromatographic. Sci.,46(2), 144-149.

Weinberger, M.; Hendeles, L. (1996). Theophylline in asthma. N. Engl, J. Med., 334(21), 13801388.

Yang, J.K.; Ha, K.S.; Baek, H.S.; Lee, S.S.; Seo, M.L. (2004). Amperometric Determination of Urea Using Enzyme-Modified Carbon Paste Electrode. Bull. Korean Chem. Soc., 25(10), 1499.

Zhou, M.X.; Guan, C.Y.; Chen, G.; Xie, X.Y.; Wu, S.H. (2005). Determination of theophylline concentration in serum by chemiluminescent immunoassay. J. Zhejiang. Univ. Sci. B., 6(12), 1148-1152. 